\title{
Perilaku Disolusi Ketoprofen Tersalut Gel Kitosan-Karboksimetilselulosa (CMC)
}

\author{
Purwantiningsih Sugita*, Suminar Setiati Achmadi, dan Yuyu Yundhana \\ Departemen Kimia, Fakultas Matematika Ilmu Pengetahuan Alam, Gd. Fakultas Peternakan W2 Lt. 4-5, \\ Jl. Agatis Kampus IPB Darmaga, Bogor 16680
}

Diterima 20-02-2009

Disetujui 28-12-2009

\begin{abstract}
Study dissolution behaviour of ketoprofen through optimum chitosan-CMC microcapsule has been carried out. Into $228.6 \mathrm{ml} \mathrm{of} 1.0 \%(\mathrm{w} / \mathrm{v})$ chitosan solution in $1 \%(\mathrm{v} / \mathrm{v})$ acetic acid, $38.1 \mathrm{ml}$ of CMC solution was added with concentration variation of $0.075 ; 0.0875$; and $0.10 \%(w / v)$. Afterwards, $7.62 \mathrm{~mL}$ of glu was added slowly under stirring, with concentrations varied: $3 ; 4.5$; and $6 \%(\mathrm{v} / \mathrm{v})$. All mixtures were shaked for 20 minutes for homogenization. Into each microcapsule mixture for ketoprofen, a solution of $2 \mathrm{~g}$ of ketoprofen in $250 \mathrm{~mL}$ of $96 \%$ ethanol was added. Every mixture was then added with $5 \mathrm{ml}$ of $2 \%$ Tween- 80 and stirred with magnetic stirrer for an hour at room temperature. Conversion of suspension into fine powders/granules (microcapsules) was done by using spray dryer. The dissolution behaviour of optimum ketoprofen microcapsules were investigated in gastric and intestinal medium. Microcapsule morphology before and after dissolution as well as empty microcapsule (blank) were observed with SEM. Spray drying process had successfully coated ketoprofen in chitosan-CMC microcapsule. Optimization by using Minitab Release 14 software showed that among the microcapsule compositions studied, CMC and glu of $0.0925 \%(\mathrm{w} / \mathrm{v})$ and $3.01 \%(\mathrm{v} / \mathrm{v})$, respectively, optimum to coat ketoprofen at constant chitosan concentration $1.0 \%$ (w/v). Result of SEM morphology and In vitro dissolution profile showed that ketoprofen in chitosan-CMC microcapsule was relatively well than chitosan-guar gum microcapsule. Kinetically, dissolution of ketoprofen from microcapsule in intestinal $\mathrm{pH}$ condition was first order with release rate constant, $k$, of $7.285 \times 10^{-4} \% \mathrm{~min}^{-1}$ and release half-time, $t_{1 / 2}$, of approximately 15 hours.
\end{abstract}

Keywords: chitosan-CMC, dissolution, ketoprofen, microcapsules

\section{PENDAHULUAN}

Ketoprofen merupakan komponen aktif yang sering dijumpai dalam obat rematik komersial. Komponen ini berfungsi sebagai analgesik, anti-peradangan, dan antipiretik yang menghambat sintesis prostaglandin. Waktu paruh eliminasinya sekitar 1-3 jam, sehingga obat ini harus sering dikon-sumsi (3-4 kali sehari). Penggunaan ketoprofen pada dosis tinggi dapat menyebabkan iritasi pada lambung dan usus. Oleh karena itu, diperlukan sistem pengantaran obat yang khusus agar kekurangan tersebut dapat diminimumkan.

Salah satu cara untuk mengatasi kelemahan tersebut ialah dengan menyalut obat dalam bentuk mikrokapsul. Bentuk sediaan obat tersebut disukai karena dapat menghasilkan efek terapetik (penyembuhan) dalam jangka panjang, memper-kecil efek samping akibat fluktuasi kadar obat dalam plasma darah, dan mengurangi frekuensi pemberian obat (Sutriyo et al., 2005).

\footnotetext{
*Telp: +62818686194

Email: ugiet@yahoo.com
}

Kitosan merupakan polimer bersifat polikationik dalam suasana asam, non-toksik, biokompatibel, dan biodegradabel. Kitosan pernah digunakan sebagai penyalut obat antihipertensi propanolol hidroklorida (Sutriyo et al., 2004), hanya saja kekuatan mekanik gelnya rendah sehingga perlu modifikasi.

Modifikasi gel kitosan pernah dilakukan dengan penambahan poli (vinilalkohol) (PVA) sebagai interpenetrating agent (IPN) dan glutaraldehida sebagai penaut silang (Wang et al., 2004). Modifikasi lainnya dengan penambahan hirokoloid sebagai IPN yaitu gom guar (Sugita et al., 2006a), alginat (Sugita et al., 2006b), CMC (Sugita et al., 2007a), dan gom xantan (Sugita et al., 2007b). Modifikasi ini meningikatkan kekuatan mekanik gel kitosan dan waktu pembentukan gel menjadi lebih cepat.

Efektivitas penyalutan ketoprofen oleh membran gel kitosan termodifikasi-gom guar dengan penaut silang glutaraldehida telah dipelajari melalui uji difusi dan disolusi. Nata et al., (2007) melaporkan bahwa difusi ketoprofen melalui membran tersebut diawali dengan 
proses pembengkakan (swelling) yang diikuti oleh pembukaan pori-pori membran sehingga obat lepas dari matriks. Sugita et al., (2007c) melaporkan bahwa hasil uji disolusi mikrokapsul tersalut kitosan-gom guar pada medium buatan untuk lambung (larutan $\mathrm{KCl}-\mathrm{HCl} \mathrm{pH} \mathrm{1,2),}$ foto SEM-nya menunjukkan bahwa setelah menit ke 30 proses disolusi, mikrokapsul ketoprofen terurai dan hancur sehingga pelepasan menjadi tidak terkendali. Sementara di medium buatan untuk usus (larutan bufer fosfat $\mathrm{pH} 7,4$ ) sampai menit ke 90, ketoprofen lepas terkendali dan mikrokapsul masih menyalut kadar ketoprofen sekitar $31,5 \%$, tetapi waktu pelepasannya terlalu cepat, yaitu sekitar 15 menit. Oleh karena itu, perlu perbaikan sistem penyalutan ketoprofen supaya pelepasannya di medium lambung terkendali dan waktu pe-lepasannya di medium usus tidak terlalu cepat.

Tiyaboonchai dan Ritthidej (2003) pernah melakukan penyalutan indometasin dengan gel kitosanCMC, hanya saja tidak ada data uji disolusinya. Sementara, Sugita et al., (2007a) telah melakukan pengukuran sifat reologi gel tersebut yang dioptimalisasikan sebagai sistem pengantaran obat. Kondisi optimum untuk larutan kitosan 2,5\%, digunakan konsentrasi glutaraldehida, dan CMC berturut-turut 6\%, dan $0,88 \%$ yang memberikan sifat reologi kekuatan gel, titik pecah, ketegaran, pembengkakan dan pengerutan berturut-turut $738,923 \mathrm{~g} / \mathrm{cm}^{2}, 1,0685 \mathrm{~cm}, 3,5095 \mathrm{~g} / \mathrm{cm}$, $5,3373 \mathrm{~g}$ dan 1,2084 g. CMC tidak larut dalam asam lambung, tetapi larut dalam cairan basa di usus (Awalludin 2004). Sifat inilah yang menyebabkan CMC digunakan untuk pembuatan tablet atau serbuk obat dengan cara salut enterik. Berdasarkan penelusuran pustaka, mikrokapsul ketoprofen tersalut gel kitosanCMC dengan penaut-silang glutaraldehida dan perilaku disolusinya. belum pernah dilakukan.

Penelitian ini bertujuan membuat mikrokapsul ketoprofen dan mengamati perilaku disolusinya secara in vitro. Mikrokapsul ketoprofen dibuat dengan meragamkan konsentrasi CMC, dan glutaraldehida, sedangkan konsentrasi larutan kitosan dibuat tetap 1\% (b/v) dengan menggunakan metode pengeringan semprot. Uji disolusi dilakukan selama 2 jam baik dalam medium buatan lambung dan usus dengan pengambilan alikuot setiap 20 menit. Pengaruh waktu terhadap pelepasan ketoprofen dikaji dengan metode regresi linear, sehingga diperoleh nilai orde reaksi, konstanta laju (k) dan waktu paruh pelepasannya. Sementara morfologi mikrokapsul diamati dengan alat SEM.

\section{BAHAN DAN METODE}

Sintesis mikrokapsul (Sugita et al., 2007a). Sebanyak 228,6 ml larutan kitosan 1\% (b/v) ditambahkan ke dalam 38,1 ml larutan CMC dengan ragam konsentrasi 0.050; 0.075; dan 0,100\% (b/v) yang nilai $\mathrm{pH}$-nya telah diatur menjadi 4. Kemudian larutan diaduk sampai homogen dengan kecepatan 600 rpm. Selanjutnya, sebanyak 7,6 ml glutaraldehida dengan ragam konsentrasi $3,4,5$, dan $6 \%$ (v/v) ditambahkan tetes demi tetes sambil terus diaduk selama 20 menit. Kemudian ke dalam larutan terebut dimasukkan larutan ketoprofen yang telah dibuat dengan melarutkan $2 \mathrm{~g}$ ketoprofen dalam $250 \mathrm{ml}$ etanol $96 \%$ untuk membuat suspensi larutan kitosan-CMC-ketoprofen. Selanjutnya, ke dalam suspensi tersebut ditam-bahkan $5 \mathrm{ml}$ Tween$80,2 \%$ (v/v). Campuran akhir diaduk dengan kecepatan 600 rpm selama 1 jam pada suhu ruang. Pengubahan suspensi menjadi mikrokapsul dengan alat pengering semprot. Alat pengering semprot yang digunakan mempunyai diameter lubang $1,5 \mathrm{~mm}$, suhu inlet dan outlet berturut-turut $170-185^{\circ} \mathrm{C}$ dan $65-95^{\circ} \mathrm{C}$, laju alir pompa 60 rpm, dan tekanan semprot pada skala 2 bar. Pada penelitian ini setiap perlakuan dibuat $2 x$ ulangan dan juga dibuat mikrokapsul tanpa ketoprofen.

Optimalisasi Mikrokapsul. Sebanyak $500 \mathrm{mg}$ mikrokapsul diekstraksi dengan $75 \mathrm{ml}$ etanol 96\% sebanyak 3 kali selama 3 jam dengan penggantian pelarut setiap jam. Konsentrasi ketoprofen yang terekstraksi diukur dengan menggunakan spektrofotometer UV pada panjang gelombang $254,6 \mathrm{~nm}$. Selanjutnya, data dioptimalisasi dengan mengguna-kan metode RSM dalam piranti lunak Minitab Release 14.

Uji Disolusi Secara In Vitro (Depkes 1995). Mikrokapsul pada kondisi optimum diuji disolusinya dengan menggunakan alat disolusi tipe 2 (metode dayung). Sebanyak 500 mg mikrokapsul dimasukkan ke dalam $500 \mathrm{~mL}$ larutan medium lambung dan usus pada chamber alat disolusi. Medium buatan untuk lambung berupa campuran larutan $\mathrm{KCl}-\mathrm{HCl}(\mathrm{pH} \mathrm{1,2)}$, sedangkan usus berupa larutan bufer fosfat $\mathrm{pH} 7,4$ selama 120 menit pada suhu $(37 \pm 0,5)^{\circ} \mathrm{C}$ dengan kecepatan pengadukan $150 \mathrm{rpm}$. Pengambilan alikuot dari mikrokapsul dilakukan setiap 20 menit sekali sebanyak $10 \mathrm{ml}$. Setiap kali pengambilan alikuot, ke dalam chamber digantikan dengan larutan mediumnya lagi sesuai dengan jumlah volume yang diambil. Konsentrasi ketoprofen dalam larutan alikuot diukur dengan spektrofotometer UV/Vis pada panjang 
gelombang $258 \mathrm{~nm}$ (untuk medium lambung) dan $260 \mathrm{~nm}$ (untuk medium usus). Selanjutnya data dikaji kinetikanya untuk penentuan orde reaksi, tetapan laju reaksi $(\mathrm{k})$ dan waktu paruh $\left(\mathrm{t}_{1 / 2}\right)$ lepasnya ketoprofen dari matriks.

\section{HASIL DAN PEMBAHASAN}

Optimalisasi Mikroenkapsulasi. Kondisi optimum ditentukan berdasarkan bobot ketopofen terbesar yang diperoleh dari hasil ekstraksi mikro-kapsul dengan menggunakan peranti lunak Minitab Release 14. Gambar 1. menunjukkan bahwa makin tinggi konsentrasi $\mathrm{CMC}$, kandungan ketoprofen yang tersalut cenderung naik. Dalam hal ini, bertambahnya konsentrasi CMC diduga melemah-kan taut silang diantara kitosan sehingga kekuatan gel cenderung lemah (Sugita et al., 2007a), akibatnya jumlah ktoprofen yang tersalut makin banyak. Sementara, peningkatan konsentrasi glutaraldehida cenderung menurunkan kandungan ketoprofen yang tersalut. Dalam hal ini, bertambahnya konsentrasi glutaraldehida menyebab-kan taut silang jejaring kitosan semakin rapat sehingga ketoprofen sulit masuk ke dalam matriks (Sugita et al., 2007a).

Dari Gambar 2 terlihat bahwa mikrokapsul dengan kandungan ketoprofen lebih besar dari 55\% diperoleh pada kisaran konsentrasi CMC dan glutaraldehida berturut-turut sebesar $(0,085-0,10) \%(b / v)$ dan $(5,7-6,0) \%(v / v)$. Pada kondisi ini suspensi membran menunjukkan sifat gelnya sehingga kekuatan mekaniknya mampu menahan ketoprofen yang tersalut lebih banyak, tetapi nisbah konsentrasi tersebut tidak dapat digunakan pada penelitian ini karena sulitnya proses pembentukan mikrokapsul dengan alat pengering semprot. Sementara, mikrokapsul dengan kandungan ketoprofen lebih kecil dari $41 \%$ diperoleh saat konsentrasi CMC dan glutaraldehida berturut-turut pada konsentrasi lebih rendah dari $0,075 \%(b / v)$ dan $5,5 \%(\mathrm{v} / \mathrm{v})$.

Hasil analisis RSM menunjukkan bahwa dengan konsentrasi larutan kitosan $1 \%(\mathrm{~b} / \mathrm{v})$ diperoleh konsentrasi CMC-glutaraldehida optimum berturut-turut sebesar 0,0925\% (b/v) dan 3,01\% (v/v) dengan kadar ketoprofen tersalut sekitar 137,50 gram. Sementara, kondisi optimum ketoprofen tersalut gom guar pada larutan kitosan 1,75\% (b/v) diperoleh saat konsentrasi gom guar dan glutaraldehida berturut-turut sebesar.

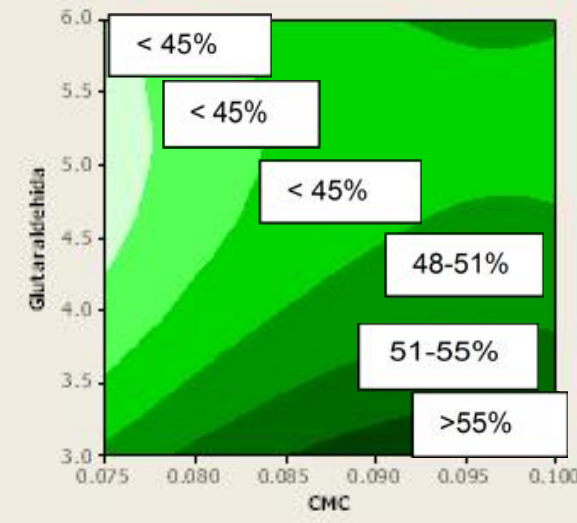

Gambar 1. Pengaruh konsentrasi CMC dan glutaral dehida terhadap \% ketoprofen yang terlepas dari matriks gel kitosan-CMC

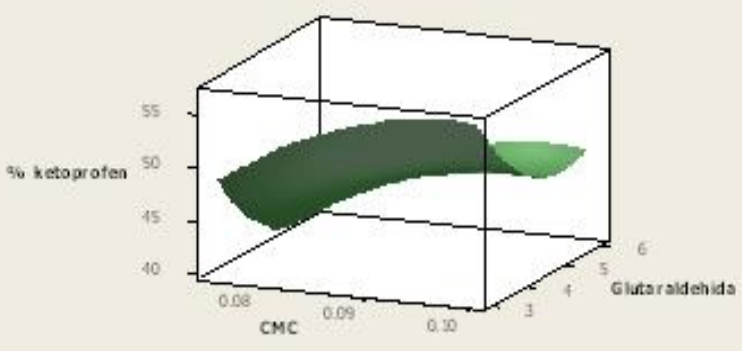

Gambar 2. Kondisi optimum nisbah konsen-trasi CMC dan glutaraldehida (inset $\square=$ daerah optimum, $\square=$ daerah minimum)

0,35\% (b/v) dan 3,75\% (v/v) dengan jumlah ketoprofen tersalut sebanyak 146,51 mg (Sugita et al., 2007a).

Disolusi Mikrokapsul. Uji disolusi berguna untuk melihat laju pelepasan ketoprofen yang tersalut matriks gel kitosan-CMC. Mikrokapsul uji adalah mikrokapsul pada kondisi optimum.

Pelepasan ketoprofen dari matriks gel kitosanCMC dikontrol oleh proses difusi obat melalui matriks. Mekanisme difusi ketoprofen tersalut kitosan-CMC mirip dengan ketoprofen tersalut kitosan-gom guar. Sutriyo et al., 2005) menyatakan bahwa jika lapisan terhidrasi dapat dipertahankan selama waktu tertentu, maka kecepatan pelepasan obat dikontrol oleh difusi dan pola pelepasannya akan linear dengan akar waktu. Sebaliknya, jika lapisan terhidrasi tidak dapat dipertahankan maka kecepatan pelepasan obat dikontrol oleh proses erosi matriks dan pola pelepasannya linear terhadap waktu. Nata et al., 2007) menyatakan bahwa mekanisme difusi ketoprofen tersalut kitosan-gom guar diawali dengan proses pembengkakan saat membran bersentuhan dengan cairan, selanjutnya pembentukan 
dan pembukaan pori membran sehingga obat terlepas dari matriks. Semakin tebal lapisan gel yang harus dilewati ketoprofen, semakin besar penghalang yang harus dilewati ketopro-fen untuk berdifusi keluar (Sutriyo et al., 2005).

Gambar 3 memperlihatkan kurva pengaruh waktu terhadap pelepasan ketoprofen rerata pada medium buatan untuk lambung dan usus. Pada 20 menit pertama, jumlah ketoprofen yang terlepas dari matriks pada medium lambung dan usus berturut-turut sebesar $11,4 \%$, dan $38,8 \%$. Selanjutnya, laju lepasan ketoprofen setelah menit ke 20 terlepas sedikit demi sedikit, perlahan dan terkendali. Bila dibandingkan dengan ketoprofen tersalut gel kitosan-gom guar, jumlah lepasan ketoprofen pada menit ke-15 dari medium lambung dan usus berturut-turut sebesar $55,0 \%$, dan $51,4 \%$ dan pada medium lambung setelah menit ke 30 mikrokapsul hancur, sehingga lepasnya ketoprofen tidak terkendali, sementara pada medium usus ketoprofen lepas sedikit demi sedikit, perlahan dan terkendali (Sugita et al., 007c) seperti halnya ketoprofen tersalut kitosan-CMC. Hal ini menunjukkan bahwa matriks gel kitosan-CMC mampu mengendalikan laju lepasan ketoprofen baik pada medium lambung maupun usus. Terkendali lepasnya ketoprofen tersalut gel kitosanCMC diharapkan dapat menurunkan efek iritasi pada saluran pencernaan. Awalludin (2004) melaporkan bahwa CMC tidak larut dalam asam lambung, tetapi larut dalam cairan basa di usus.

Pada penelitian ini, lamanya waktu proses disolusi 2 jam dengan jumlah lepasan ketoprofen rerata tersalut kitosan-CMC 41,9\%, sedangkan Sugita et al., (2007c) melaporkan bahwa jumlah lepasan ketoprofen rerata

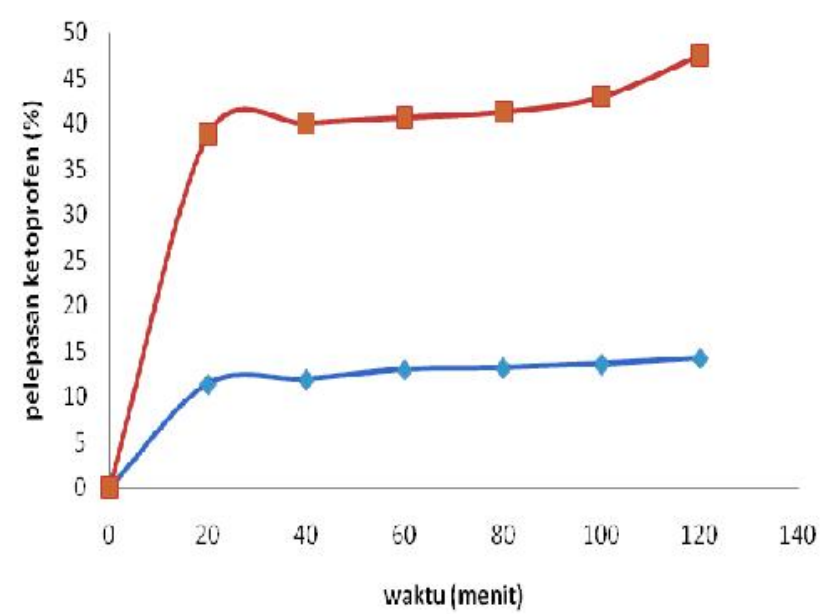

Gambar 3. Pengaruh waktu terhadap \% ketoprofen rerata yang ter-lepas dari matriks pada medium lambung $(-)$ dan usus (-) tersalut kitosan-gom guar setelah 90 menit disolusi sebesar $67.5 \%$. Sugita et al., (2007a) melaporkan nilai pembengkakan kitosan-CMC sebesar $5.3 \mathrm{~g}$, sedangkan pada kitosan-gom guar sebesar $4.1 \mathrm{~g}$ (Sugita et al., 2006a). Hal ini sesuai dengan pernyataan Sutriyo et al., (2005) yang menyatakan bahwa semakin tebal lapisan gel yang harus dilewati, semakin besar penghalang yang harus dilewati ketoprofen untuk berdifusi keluar. Kondisi ini menguatkan bahwa gel kitosan-CMC lebih baik dibandingkan gel kitosan gom guar sebagai matriks sediaan lepas lambat. Tiyaboonchai dan Ritthidej (2003) melaporkan bahwa dibutuhkan waktu 24 jam untuk melepaskan seluruh indo-metasin dari matriks kitosan-CMC, sedangkan Yamada et al., (2001) menyatakan bahwa untuk melepaskan $75 \%$ ketoprofen dari matriks kitosan-etilselulosa membutuhkan waktu 24 jam.

\section{Kinetika Disolusi ketoprofen dalam medium}

usus. Data hasil uji disolusi mikrokapsul optimum digunakan untuk mempelajari kinetika pelepasan ketoprofen dari matriksnya. Parameter yang ditentukan meliputi orde reaksi, nilai $\mathrm{k}$ dan $\mathrm{t}_{1 / 2}$ ketoprofen.

Penentuan orde reaksi dilakukan dengan menggunakan metode grafis, yaitu dengan melihat nilai koefisien determinasi, $R^{2}$ yang diperoleh dari kurva hubungan antara konsentrasi ketoprofen dan waktu (Atkins, 1990). Hasil analisisnya menunjukkan bahwa lepasnya ketoprofen dari matriks gel kitosan-CMC mengikuti orde reaksi ke-1 (Gambar 3), karena nilai $R^{2}$ pada orde tersebut lebih besar dibandingkan untuk orde 0, 2, dan 3 yaitu 0,9931 (99,31\%). Berdasarkan kurva hubungan alur logaritma konsentrasi ketoprofen yang ma-sih tersalut terhadap waktu reaksi pada orde ke-1, diperoleh persamaan garis \% ketoprofen = $4,1451-7,285 \times 10^{-4} \mathrm{t}$. Dari persamaan tersebut diperoleh nilai $k$ dan $t_{1 / 2}$ berturut-turut sebesar $7,285 \times 10^{-4} /$ menit dan 15 jam. Ketorofen tersalut kitosan-cmc menunjukkan perilaku disolusi lebih baik dibandingkan ketoprofen tersalut kitosan-gom guar. Sugita et al., (2007c) melaporkan bahwa lepasnya ketoprofen tersalut gel kitosan-gom guar mengikuti reaksi orde ke-3 dengan nilai $k$ dan $t_{1 / 2}$ berturut-turut sebesar $1 \times 10^{-5} \mathrm{I}^{2} \mathrm{~mol}^{-2}$ menit $^{-1}$ dan 15 menit.

Waktu paruh dari suatu obat akan mempengaruhi masa kerja dari obat tersebut. Lelo et al., (2004) menyatakan bahwa semakin panjang waktu paruh dari obat anti-peradangan, maka semakin lama pula masa 


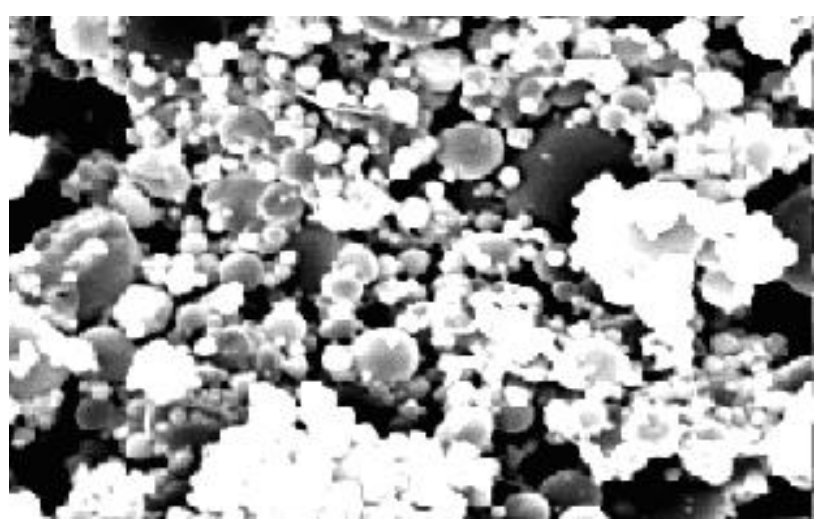

(a)

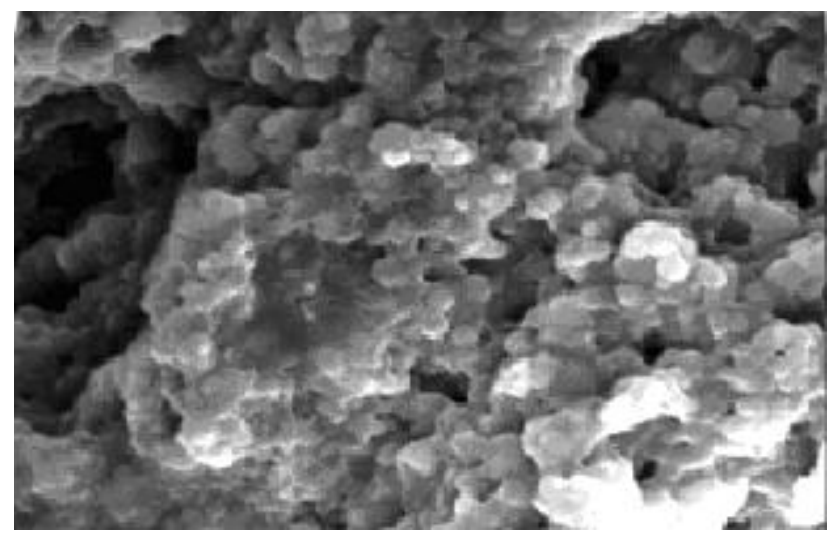

(c)

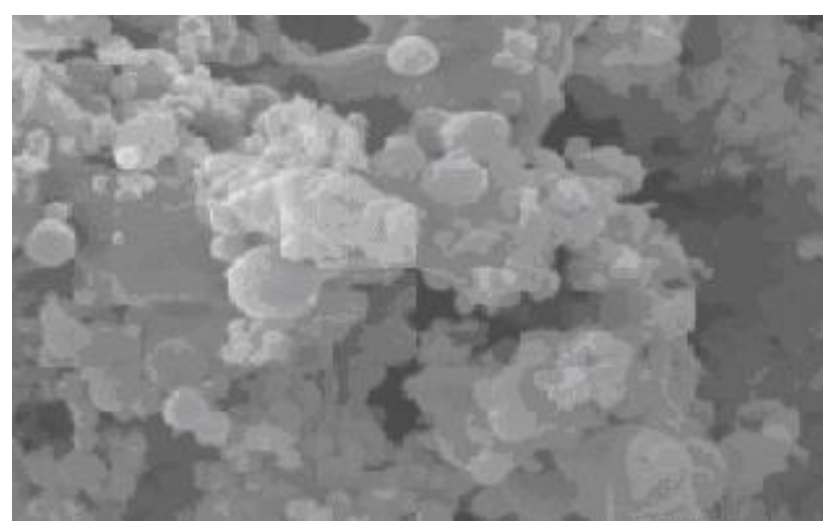

(b)

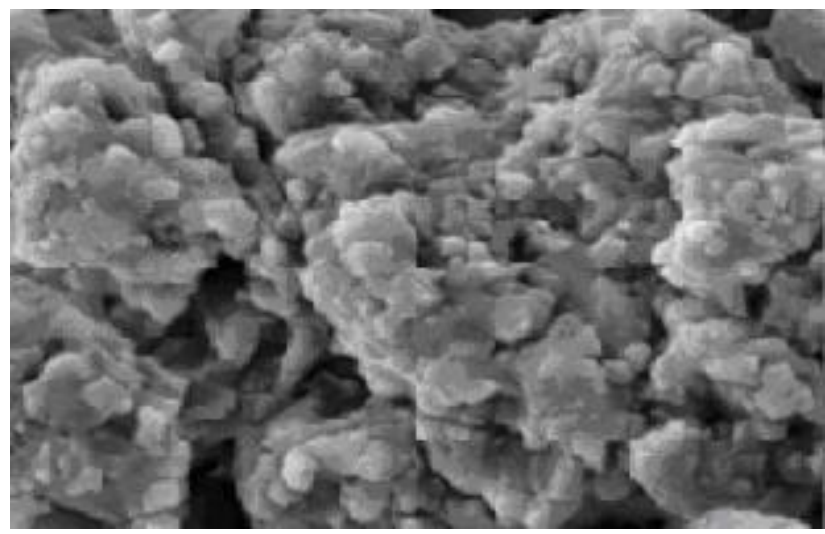

(d)

Gambar 4. SEM permukaan mikrokapsul (a) tanpa ketoprofen, (b) berisi ketoprofen (c) hasil disolusi dalam medium lambung, (d) hasil disolusi dalam medium usus. pada perbesaran $2000 x$

kerja dari obat tersebut. Sebaiknya, obat antiperadangan dapat bekerja lebih lama bahkan sampai 24 jam, sehingga obat tersebut cukup diberikan satu kali dalam satu hari. Waktu paruh ketoprofen tersalut kitosan-CMC jauh lebih lama dibandingkan dengan yang tersalut kitosan-gom guar, artinya matriks kitosanCMC mampu bekerja sebagai matriks sediaan lepas lambat.

Morfologi Mikrokapsul. Hasil analisis morfologi mikrokapsul dengan SEM menunjukkan bahwa ukuran mikrokapsul dengan penambahan keto-profen (3-12 m) lebih besar dibandingkan mikrokap-sul tanpa penambahan ketoprofen (2-5 m) (Gambar 4). Hal ini menunjukkan bahwa telah terjadi proses enkapsulasi ketoprofen oleh matriks gel kitosan-CMC.

Hasil SEM mikrokapsul setelah disolusi menit ke 120 pada medium lambung dan usus (Gambar 4c dan 4d) menguatkan mekanisme difusi yang dilakukan oleh Nata et al., (2007) pada matriks gel kitosan gom guar. Proses pembengkakkan matriks pada media usus lebih besar dibandingkan dalam medium lambung. Fenomena ini sangat baik karena matriks mampu menahan lepasnya ketoprofen yang berlebihan dalam medium lambung sehingga mengurangi akumulasi ketoprofen dalam lambung.

\section{KESIMPULAN}

Kondisi optimum penyalutan ketoprofen dicapai pada saat konsentrasi $\mathrm{CMC}$ dan glutaraldehida berturutturut $0,0925 \%(\mathrm{~b} / \mathrm{v})$ dan 3,01\% (v/v) dalam konsentrasi kitosan tetap $1 \%(b / v)$. Laju pelepasan ketoprofen dari matriks pada medium usus $(\mathrm{pH} 7,4)$ mengikuti reaksi pada orde ke-1 dengan nilai $k$ dan $t_{1 / 2}$ berturut-turut sebesar $7,285 \times 10^{-4}$ menit $^{-1}$ dan $15 \mathrm{jam}$. Hasil analisis dengan SEM menunjukkan bahwa pembengkakkan matriks pada medium usus lebih besar dibandingkan medium lambung setelah disolusi pada menit ke 120 . Matriks gel kitosan-CMC memiliki kemampuan sebagai sediaan lepas lambat lebih baik dibandingkan matriks kitosan-gum guar.

\section{UCAPAN TERIMA KASIH}

Penulis mengucapkan terima kasih kepada Direktur DP3M Direktorat Jenderal Pendidikan Tinggi Depdiknas melalui Hibah Kompetensi No. 039/HIKOM/ DP2M/2008 atas nama Dr. Purwantiningsih Sugita sebagai sumber dana penelitian ini. 


\section{DAFTAR PUSTAKA}

Atkins, P.W. 1990. Kimia Fisika. Physical chemistry. Ed ke-5. Jakarta: Erlangga.

Awalludin, A. 2004. Karboksimetilasi selulosa bakteri skripsi. Fakultas Matematika dan IImu Pengetahuan Alam. Bogor: Institut Pertanian Bogor.

Depkes, R.I. 1995. Farmakope Indonesia. Ed ke-4. Jakarta: Departemen Kesehatan RI.

Lelo, A., Hidayat, D.S., Juli, S. 2004. Penggunaan Anti-Inflamasi Non-Steroid yang Rasional pada Penanggulangan Nyeri Rematik. e USU Repository. http///www. library. usu. ac. id/download/fk/farmakologi-aznan4.pdf [22 Desember 2007].

Nata, F., Sugita, P. \& Syahriza, A. 2007. Diffusion behavior of ketoprofen through chitosan-gum guar membranes. Prosiding International Conference and Workshop on Basic and Applied Science 2007, Surabaya-Indonesia 6-7 Agustus 2007.

Sugita, P., Sjachriza, A. \& Lestari SI. 2006a. Sintesis dan optimalisasi gel kitosan-gom guar. J Nature 9: 32-36.

Sugita P, Sjachriza A, Wahyono D. 2006b. Sintesis dan optimalisasi gel kitosan-alginat. J Sains dan Teknologi Indonesia 8: 133-137.

Sugita, P., Sjachriza, A. \& Rachmanita. 2007a. Sintesis dan optimalisasi gel kitosan-karboksimetil selulosa. J. Alchemy 6(1): $57-62$.
Sugita, P., Sjachriza, A. \& Utomo, D.W. 2007b. Optimization synthesis chitosan-xanthan gum gel for metal adsorption. Prosiding $1^{\text {st }}$ International Conference on Chemical Sciences. MAT/33-4. Yogyakarta 25-26 Mei 2007.

Sugita, P., Srijanto, B., Amelia, F. \& Arifin, B. 2007c. Perilaku disolusi ketoprofen Tersalut Kitosan-Gom Guar. JSChem ITB-UKM 2007, Bandung 12-13 Desember 2007.

Sutriyo, Djajadisastra, J. \& Novitasari, A. 2004. Mikroenkapsulasi propa-nolol hidroklorida dengan penyalut etil selulosa menggunakan metode penguapan pelarut. Majalah IImu Kefarmasian 1: 193-200.

Sutriyo, Djajadisastra, J. \& Indah R. 2005. Perbandingan pelepasan pro-panolol hidroklorida dari matriks kitosan, etil selulosa, dan hidroksipropil metil selulosa. Majalah IImu Kefarmasian 2:145-153.

Tiyaboonchai, W. \& Ritthidej GC. 2003. Development of indomethacin sustained release microcapsules using chitosan-carboxymethyl cellulose complex coarcevation. Songklanakarin J. Sci Technol 25: 245-254.

Wang T, Turhan, M., \& Gunasekaram, S. 2004. Selected properties of $\mathrm{pH}$-sensitive, biodegradable chi-tosanpoly(vinyl alkohol) hydrogel. Polym Int 53: 911-918.

Yamada, T., Onishi, H. \& Machida, Y. 2001. In vitro and in vivo evaluation of sustained release chitosan-coated ketoprofen microparticles. Yakugaku Zasshi 121: 239245. 